\title{
A Study on Optimal Control of Ship Propulsion Systems
}

\author{
○学 三塩 亮一 (神戸市立高専) 正 加岛 正 (神戸市立高専)
}

Ryoichi MISHIO, Kobe City College of Technology, Gakuenhigashimachi8-3, Nishi-ku, Kobe Tadashi KASHIMA, Kobe City College of Technology

\begin{abstract}
A ship propulsion system shows complex dynamic behaviors and consideration of dynamic characteristics is indispensable for development of effective control system. In this paper, the propulsion system is mathematically modeled and an optimal control scheme is formulated in order to transit the system in shorter time under proposed performance criterion. Finally, system simulations are conducted and advantages of the propose control system have been quantitatively evaluated.
\end{abstract}

Keywords: Propulsion System, Optimal Control

\section{1.はじめに}

船舶の推進に関する主要な要素のエンジン部および軸系 を含むプロペラ部，船体部を統合して舶用推進システムと 呼ぶ. 現在, 舶用推進システムに関する研究の多くはエン ジンを主体とした制御について議論している(1).しかし， エンジンの忘答は船体部に比へ非常に早いため(2), エンジ ンが目標值に達したとしてもシステム全体が平衡状態に達 していないという現象が生じる．従って，システム全体の 制御性能の向上を図るためには船体部の動特性を考虑する 必要がある。

本研究では船体部を含めた枠組みで舶用推進システムの 最適制御について論じる。まず，各々の要素の応答特性を 考慮して，エンジン部とプロペラ部を静的システムとみな し，船体部を動的システムとしてシステムモテルを棈筑し た. 次に評価関数を定義し最適制御問題として定式化をし た。さらに，船速を従来よりも短時間で增速するための制 御法を提案し，これらの問題の解法のために最適解探索ア ルゴリズムを構築した。 また，シミュレーションを行い， 本研究で提案する最適制御システムが適切に動作すること を確認した，最後に，その成果を既存の制御システムに適 用することにより制御性能を大きく向上することを示した。

\section{2.システムモデル}

船体部は運動を 1 自由度に限定し，風圧力などの流体抵抗以 外の外力を無視すると

$$
\dot{v}=\frac{1}{M}\left\{t_{p}\left(1-t_{d}\right)-R\right\}
$$

と表現できる.ここで $v$ および $M, t_{p} ， t_{d} ， R$ はそれぞれ船速 $\mathrm{m} / \mathrm{s}$ および船体質量 $\mathrm{kg}$, プロペラスラスト $\mathrm{N}$, スラスト堿少率, 船体抵抗 N, である. プロペラ回転速度と船速の関数で決ま るプロペラスラストは

$$
t_{p}=K_{t} \rho D^{4} n^{2}
$$

と表される。ここでの $\rho, D, n$ はそれぞれ海水密度 $\mathrm{kg} / \mathrm{m}^{3}$ ， プロペラ径 $\mathrm{m}$, プロペラ回転速度 rps である. またトルク 係数 $K_{\imath}$ は線形近似すると,

$$
K_{1}=-0.4227 J+0.3331
$$

となる.なお， $J$ は前進係数であり

$$
J=\frac{v(1-w)}{n D}
$$

と定義され、ここで $w$ は伴流係数である. 結局, 船体の流 体抵抗が船速の 2 乗に比例すると考えれば, 式(1)は，

$$
\dot{v}=c_{1} v^{2}+c_{2} v \omega+c_{3} \omega^{2}
$$

となる.ここで $\omega$ はプロペラの回転速度 $\mathrm{rad} / \mathrm{s}$ である．ま た $c_{1}, c_{2}$ および $c_{3}$ は推進システムの諸元を式(1) (4)に代 入して得られる定数である.なお, エンジン部やプロペジ部 の応答性は船体部に比べ非常に小さいため, 両者ともに静 的システムとみなした，次にシステム入力を，

$$
\dot{\omega}=u
$$

と定義し，回転加速度変化最小規範に基つくく制御シスデム について考察する.

\section{3.最適制御問題}

\section{1 定式化}

舶用推進システムの運動は式(5)と式(6)で表現でき，状態 変数を $x=\left(x_{1}, x_{2}\right)^{T}=(v, \omega)^{T}$ と定義すると，

$$
\dot{\boldsymbol{x}}=f(x, u)=\left[\begin{array}{l}
c_{1} x_{1}{ }^{2}+c_{2} x_{1} x_{2}+c_{3} x_{2}{ }^{2} \\
u
\end{array}\right]
$$

となる。

次に, プロペラの回転加速度変化を最小とする制御シス テムを構築するため, 評価関数を，

$$
J=\frac{1}{2} \int_{b}^{s} u^{2} d t
$$

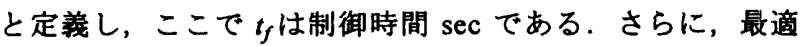
軌道を得るために随伴係数 $\lambda=\left(\lambda_{1}, \lambda_{2}\right)^{T}$ を用いてハミルト ン関数を,

$$
H=u^{2}+\lambda_{1}\left(c_{1} x_{1}^{2}+c_{1} x_{1} x_{2}+c_{3} x_{2}^{2}\right)+\lambda_{2} u
$$

と定義する.このとき，

$$
\frac{\partial H}{\partial u}=0, \quad \dot{\lambda}^{T}=-\frac{\partial H}{\partial \boldsymbol{x}}, \text { and } \dot{\boldsymbol{x}}=\frac{\partial H}{\partial \lambda}
$$

及び状態量の初期条件 $x(0)=\left(x_{1}(0), x_{2}(0)\right)^{T}$ と状態量の) 終 端条件 $x\left(t_{f}\right)=\left(x_{1}\left(t_{f}\right), x_{2}\left(t_{f}\right)\right)^{r}$ で決定される最適入力を満 足するのが最適軌道である。

3.2 最適解探索アルゴリズム

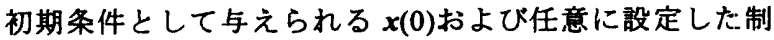
御時間 $t_{f}$ と随伴係数 $\lambda_{0}=\left(\lambda_{0_{1}}, \lambda_{O_{2}}\right)^{T}$ の初期値を用いて式(10) の微分方程式の数值解を得る.ここで得られる終端時間で の状態 $x_{f}=\left(x_{u_{f}}, x_{u_{f}}\right)^{T}$ が初期条件で与えられる $x\left(t_{f}\right)$ とは異 なるので, その謓差を,

$$
\left(\begin{array}{l}
e_{1} \\
e_{2}
\end{array}\right)=\left(\begin{array}{l}
x_{1,}-x_{1}\left(t_{f}\right) \\
x_{2,}-x_{2}\left(t_{f}\right)
\end{array}\right)
$$




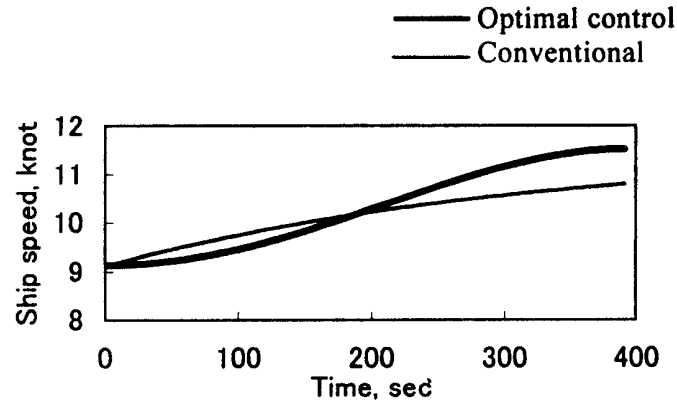

(a) Ship speed ( $25 \% \mathrm{MCR}$ to $50 \% \mathrm{MCR}$ )

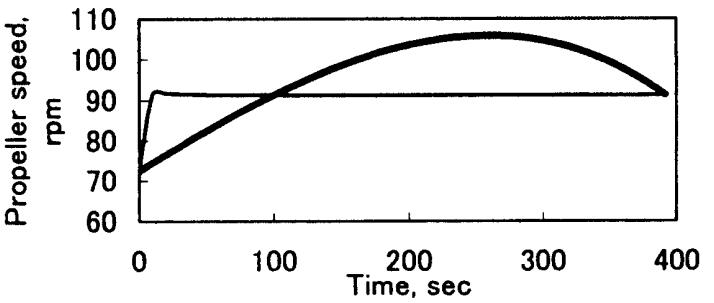

(b) Propeller speed (25\%MCR to 50\%MCR)

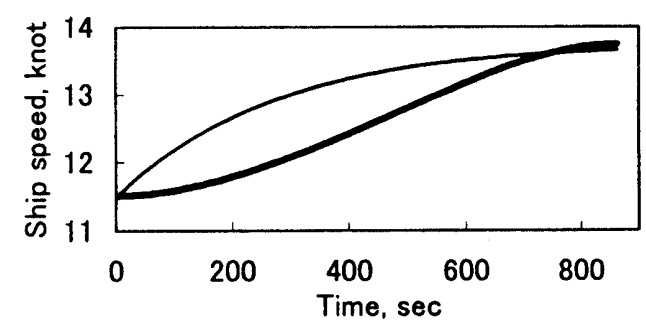

(c) Ship speed (50\%MCR to $85 \% \mathrm{MCR}$ )

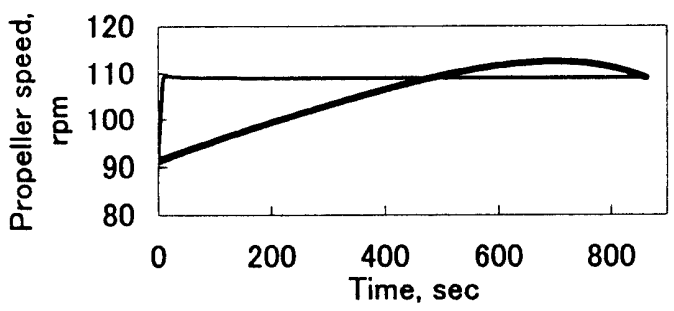

(d) Propeller speed (50\%MCR to $85 \% \mathrm{MCR}$ )

Fig. 2 Trajectory

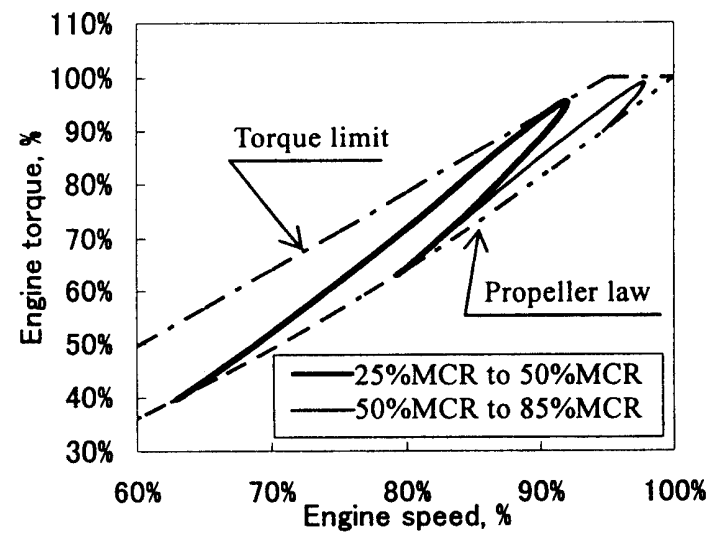

Fig.3 Engine torque
とおく．次に，一般に設定されているエンジンのトルク限 度以内で船速を最短時間で目標值まで加速する制御につい て考察する。まず，任意時間での状態 $\boldsymbol{x}$ よりエンジントル ク $q_{e}(\dot{\omega}(t), \omega(t), v(t))$ を求める. そのときのプロペラ回転速 度に対するトルク限度を $q_{e \lim }(\omega(t))$ とし，両者の差の最小 值を

$$
\varepsilon=\min \left\{q_{e \lim }\left(\omega(t)-q_{e}(\dot{\omega}(t), \omega(t), v(t))\right\}\right.
$$

とおく．このとき $\left(e_{l}, e_{2}, \varepsilon\right)^{T}$ は $\lambda_{0}$ と $t_{f}$ の関数と考えることが できるので, $\left(e_{l}, e_{2}, \varepsilon\right)^{T}$ を 0 にするための $\lambda_{0}$ と $t_{f}$ の変化量 $\Delta \lambda_{0}$, $\Delta t_{f}$ を

$$
\left(\begin{array}{l}
\Delta \lambda_{01} \\
\Delta \lambda_{02} \\
\Delta t_{f}
\end{array}\right)=-\left(\frac{\partial e_{1}}{\partial \lambda_{01}}, \frac{\partial e_{2}}{\partial \lambda_{02}}, \frac{\partial \varepsilon}{\partial t_{f}}\right)^{-1}\left(\begin{array}{l}
e_{1} \\
e_{2} \\
\varepsilon
\end{array}\right)
$$

として近似することができる。

\section{4.シミュレーション結果と考察}

提案する最適制御システムの性能を定量的に確認するた めに船のモデルを次のように設定した。

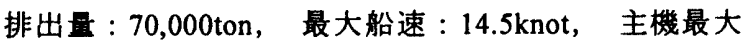

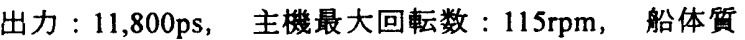
量 : $7.56 \times 10^{7} \mathrm{~kg}$ ，プロペラ径: $6.2 \mathrm{~m}$ ，プロペラと軸 系の慣性モーメント：45,000 $\mathrm{kgm}^{2}$, 軸系効率 : 0.97, 伴流係数: 0.4 , スラスト减少率: 0.18 , 流体抵抗係 数 : $1,409.1 \mathrm{Ns}^{2} / \mathrm{m}^{2}$

このモデルをもとに $25 \% \mathrm{MCR}$ から $50 \% \mathrm{MCR}$ と $50 \% \mathrm{MCR}$ から $85 \% \mathrm{MCR}$ への増速したときの最適軌道を求めた.

実際の舶用推進システムは，エンジンの回転速度を制御 量とする PID 制御を行っている.そこで，プロペラ回転速 度の最適軌道を入力としたときに実機で適性に動作するか を確認する．そのために，PID 制御の推進システムモデル で $25 \% \mathrm{MCR}$ から $50 \% \mathrm{MCR}$ と $50 \% \mathrm{MCR}$ から $85 \% \mathrm{MCR}$ 一 增速時の各々のシミュレーションを行う。また，ステップ 参照入力の PID 制御で船速を増速したときのシミュレーシ ヨンを比較のために行った。

従来の制御では，ステップ参照入力に対してプロペラ回 転速度を制御量としている。このときプロペラの動特性は 船体に比べ忘答が極端に速いため，50(s)以内に整定する。 また，船速は $25 \% \mathrm{MCR}$ から $50 \% \mathrm{MCR}$ 一增速するときの必 要な増速量に対して 70\%しか到達できなかった。この場合， システム全体が整定に至るまでは $1100(\mathrm{~s})$ 以上かかること がわかった。

一方，提案する制御方式では，従来の制御方式よりも滑 らかに変化していることから加速度を飛躍的に抑えること ができる。また，25\% MCR から 50\% MCR と 50\% MCR か ら $85 \% \mathrm{MCR}$ にそれぞれ増速したときの整定時間は，従来 に比べ非常に早く前者では 392(s), 後者では 863(s)となっ た.これより船速を従来の制御法よりも早い時間で所定の 船速へ増速できることがわかった。

\section{参考文献}

（1）田村直樹，岸本功，前田隆義，佐藤勲，“電子ガバナ制 御パラメータ最適化システムの開発”，日本舶用機関 学会誌 vol.24, No.6, 1989

(2) Tadashi Kashima, A.Seireg, "A Computer Control System for Ice-Transiting Ships", Proceeding of OMAE International Symposium Vol.I, pp.25-30, 1986 